Сидоренко Л. I., аспірантка кафедри української літератури і компаративістики Київського університету імені Бориса Грінченка

\title{
МИТЕЦЬ У «ПЕРЕВЕРНУТОМУ» СВІТІ: ОСОБЛИВОСТІ ПЕРЕХІДНОГО ХУДОЖНЬОГО МИСЛЕННЯ У ДРАМІ ЯРОСЛАВА ВЕРЕЩАКА «ДУША МОЯ ЗІ ШРАМОМ НА КОЛІНІ»
}

У статті розглянуто типологічні риси метадрами, виявлено чинники формування мета дискурсу та прийом створення у драмах театру в театрі, тобто "подвійної сиени», створення образа мития $i$ його модерне вивищення. У результаті дослідження драми Ярослава Верещака "Душа моя зі шрамом на коліні» узагальнено функиії мистеитва, його можливості відображати складну історичну реальність і кризову сучасність.

Ключові слова: автобіографізм, інтенція, метадискурс, метадрама, типологічні риси, авторефлексія літератури.

В статье рассмотрены типологические черты метадрамы, вылвлены факторы формирования иель дискурса и прием создания в драмах театра в театре, то есть «двойной сиены», создание образа художника и его современное возвышения. В результате исследования драмы Ярослава Верещака «Душа моя со шрамом на колене» обобщень функиии искусства, его возможности отображать сложную историческую реальность $и$ кризисную современность.

Ключевые слова: автобиографизм, интенция, метадискурс, метадрама, типологические черты, авторефлексия литературы.

The article is devoted to the typological characteristics of the metadram. Investigated here are the forming factors of metadiscourse and the reception of theater's theater's drams, that is "double scene», creation of the image of the artist and his modern sight. The article summarizes the dram of Yaroslav Vereshchak, "My Soul with Scar on the Knee» the functions of art, its ability to reflect complex historical reality and crisis modernity.

Keywords: autobiographism, intention, metadiscourse, typological characteristics, autoreflection of the literature. 
Метою дослідження є характеристика образу митця у творах Ярослава Верещака 2000-х років у контексті перехідного художнього мислення, культурних змін межі століть і їх рефлексії літературою.

Актуальність теми дослідження зумовлена потребою виокремлення у творі Я. Верещака типологічних рис метадрами та характеристика специфічних особливостей авторефлексії літератури, які інспіровані пошуком мистецтвом слова нової ідентичності на зламі культурних i художніх парадигм i світобаченням яскравого митця. Драма «Душа моя зі шрамом на коліні» може сприяти оприявленню своєрідності методискурсу та способів його моделювання в сучасній українській літературі та iї пошуковому, експериментальному крилі - драматургії. «Нова хвиля» 1980-х змінила обличчя вітчизняної драматургії, увібрала художні пошуки письменників-новаторів Я. Стельмаха, В. Борисовича, П. Висоцького, М. Віргінської, Л. Хоролець, що являє собою недостатньо вивчений феномен. Акцентуючи на цьому увагу, дослідники шукають найбільш ефективний ракурс розгляду цього явища.

За думкою I. Мамчура, драматург мислиться Ярославом Венрещаком як актуальна фігура сучасної культури. Якщо Н. Корнієнко говорить про діагностичну функцію сучасного театру, то I. Мамчур підкреслює, спираючись на твори Я. Верещака, поєднання в драматургії сміливого аналізу стану культури й традиційної дидактичної функції, розуміння письменником «виховної місї̈ сучасного театру як щчирого й відвертого співрозмовника» [Мамчур 1988:40].

Очевидною є складність і багатомірність образу головного героя п’єси «Душа моя зі шрамом на коліні». Ця особливість зумовлена вмілим поєднанням декількох аспектів зображення, стереоскопічністю бачення (кожен із персонажів дає свій «портрет», своє уявлення про головного героя, а він, своєю чергою, схильний до серйозних, комічних, ліричних, провокаційних автохарактеристик). Підкреслюється також антиномічність натури, що посилюється екзистенціальною розгубленістю. 
Можемо виокремити домінантні авторські інтенції зображення героя, різні ракурси (буттєві, екзистенціальні, побутові, автобіографічні) художнього дослідження характеру митця.

Герой, з одного боку, моделюється як найширше художнє узагальнення, як людина взагалі, яка до того ж опиняється в невідворотній для кожного глядача і читача ситуації підбиття життєвих підсумків і самовизначення перед лицем смерті, на кордоні переходу в інший світ. Обігруючи тезу Воланда про те, що людина «раптово смертна», Славко підводить життєвий підсумок, фіксує свої гріхи й світлі орієнтири, переглядаючи надбання, власне, піддає переоцінці шкалу цінностей і фіксує перевертання на ï вісі. Ця традиційна ситуація посилюється притаманним саме перехідному мисленню апокаліптичним, драматичним сприйняттям світу. Слав-Ко-Ко переживає свій власний апокаліпсис. Його оточують із ним вступають у діалог душі - тіні усіх загиблих і любимих ним істот, тих, що формували його власний космос, навіть «рай»це квіти пані Опунція і Гусманія, біла миша Ійсо, кішка Фірся, собака Сер Тобі та ін. Причому деякі померли через його персональну недбалість.

Олена Бондарева, розкриваючи підтексти драми Ярослава Верещака «Душа моя зі шрамом на коліні», виокремлює три системотворчі дискурси. Перший - чаклунська казка. Я. Верещак, за думкою дослідниці, обіграє параметри іiі образної системи. Другий план підтекстів, як демонструє О. Бондарева, - євангельський. Акцентується, зокрема, «неологічне» «розп’яття героя» [Бондарева 2006:275], яке за логікою авторефлексії перетворюється на метафізичне «саморозпинання протагоніста у боротьбі за можливість донести власні твори до глядача / читача <...>» [Бондарева 2006:275]. Третій дискурс, за думкою дослідниці, - літературоцентричний. Він створений «багатоярусними кодовими культурними цчитатами» [Бондарева 2006:275], серед яких виокремлюється концепт запроданої душі.

Особливу інтимність переживань забезпечує автобіографізм i автофікціональність образу. Вони пропонують більш вузький, але переконливий, «документований» ракурс зображення героя. Головний герой 
означується як «Я», йому дається якщо не власне ім’я біографічного автора, то принаймні натяк на нього: Ярослав - «Слав-Ко-Ко». Зберігається, хоч i подається в іронічному ключі і статус: «Я - письменник Слав-Ко-Ко, член національної спілки письменників», «відомий», «драматург», «лауреат» тощо.

Оповідач-митець в експериментальному романі Валентина Катаєва «Діамантовий мій вінець» (теж частково автобіографічний та частково автофікційний, карикатурний образ) вважав наявність саме такої сповідальної авторефлексії та самозасудження ознакою справжнього таланту, критерієм визначення великих поетів і «малих геніїв». Поєднуючи спомини із фантазіями на тему творчості, він вбачав таке «саморозпинання» у віршах i творчій поведінці своїх знайомців сучасників - Сергія Єсеніна, Едуарда Багрицького, зрештою, впізнавав його у собі.

Загальнолюдське значення образу митця, філософське осягнення проблеми творчості посилює прийом інтерактивного спілкування з глядачами й принцип «подвійної сцени». Автор вважає, що поставлені проблеми мають зачіпати кожного. А протагоніст фактично пропонує глядачеві приміряти на себе екзистенціальну ситуацію переходу, самоаналізу, пошуків виходу 3 глухого кута. Паралельно пробуджуються саме творчі потенції глядачів, їх залучення до метадискурсу в аспекті життєтворення й моделювання естетичних «сценаріїв» тексту долі. «Господи, щуо ж робити? (Кричу до глядачів) Гей, люди, будь ласка, давайте разом подумаємо - щзо робити? Ну, одна голова добре, а триста сімдесят п'ять... чи скільки вас тут?» [Верещак 2004:118].

I одночасно така інтерактивність, яка часто перетворюється на гру у пошук «сценаріїв», у визначення ролей та амплуа, знімає зайвий дидактичний пафос, очуднює проблему, підсилює умовність, театральність дії, але не руйнує образне узагальнення - зображення особистості у пошуках свого справжнього «Я». Прикладом може слугувати блюзнірське звернення Слав-Ка-Ка до страшного Чорного Ангела як до режисера дійства (смерті, спрямування душі ло пекла), яке можна розіграти і тим зняти страх перед переходом, очуднити ситуацію авторефлексії. «То, може, дозволиш хоч раз пошити кохану публіку в 
дурні, га? < ..> Я пропоную присутнім тут глядачам зіграти у своєрідну гру, щзось на зразок ребуса: окремі думки та речення, з яких треба скласти сюжет» [Верещак 2004:104].

Найширший екзистенціальний ракурс зображення сприяє увиразненню метаакценту, але й одночасно поглинає його, «ставить на місце» й змушує до переоцінки, виокремленню сутності творчості. Не дарма апокаліптичний персонаж Чорний Ангел, питаючи героя «Что ти, людино?», не задовольняється відповіддю «лауреат, член Наџіональної спілки письменників», іронічно ставиться до виправдань вимогами часу, не пробачає митцю крутійства і навіть стидається за весь рід людський («Чорний Ангел дивно усміхнувся $i$ вперше за всю нашу розмову відвів очі. Так, наче йому стало соромно не лише за мене, а й за весь рід людський») [Верещак 2004:103].

I все ж таки вибір у ролі головного героя саме творчої особистості $\epsilon$ принциповим для концепції твору. Вибір, на наш погляд, пов’язаний із декількома особливостями авторської інтерпретації сучасної перехідної епохи, культурної кризи.

По-перше, герой письменник глибоко переживає драматичні особливості доби й висвітлює сам процес їх художньої інтерпретації, пошук адекватної «мови» втілення динамічної картини світу й характеру людини переломної доби.

По-друге, деформації «перевернутого» світу можуть бути чітко розглянуті саме через призму зміни уявлень про роль мистецтва в суспільстві i культурі, статус митця, у демонстрації зміни пріоритетів, ідеалів в цілому і архетипних моделей творця зокрема (світського святого, пророка, божого обранця, моста між світами, сакральної жертви; жебрака, що живе лише творчістю i, за моделлю Сковороди, «не ловиться» світом і його спокусами тощо).

Крім того, саме митець, за думкою культурологів і літературознавців (Д. Тойнбі, М. Хренова, А. Ханзен-Леве, 3. Мінц, Г. Мережинської) $є$ актуальною фігурою перехідних часів, лідером, який iз маргінесу 
переміщається у центр системи культури та втілює активний пошук нових можливостей іï розвитку в умовах кризи. Поєднання усіх цих ракурсів зображення людини перехідного часу й митця, що осмислює свій новий статус у «перевернутому» світі, зустрічаємо у п’єсі Ярослава Верещака.

«Перевертання» світу втілює і рефлектує протагоніст - драматург, що перетворився із митця на ділка. Переміщення центру й периферії в системі культури констатує і містичний Чорний Ангел, «Божий посланець», що втілює вищій ракурс оцінки змін у світі. Недарма він називає Слав-Ка-Ка «міняйлом», a діяльність драматурга оцінює негативним порівнянням із «Грою у бісер» Г. Гессе, тобто із високим модерністським орієнтиром, елітарним зразком, від якого нинішній літератор відійшов максимально далеко у бік заробітчанства й крутійства. За словами Чорного Ангола Славко поміняв гру в бісер на гру в бізнес, а вона, додамо, знищила літератора фізично (смерть від руки подільників-«братків») $\mathrm{i}$ майже розчинила духовно. $\mathrm{y}$ «посмертних» виправданнях протагоніст представляє себе жертвою і героєм кризового часу i «перевернутого» світу. В його інтерпретації, в новій картині світу просто помінялися місцями центр i периферія: кримінальна зона встановила свої правила життя, а «нормальні люди опинилися в тюрмі злиднів і безправ я, зони помінялися місиями» [Верещак 2004:108]. Зауважимо, що у змальованій картині світу відсутній вищій духовний ракурс, ідея гармонії, раю, в ній одне пекло заміщає інше. Відсутність духовної вертикалі демонструє повний розрив із культурною традицією, нормою в цілому та із архетипними уявленнями про митця як обранця Божого та виконувача високої місії.

Саме тим, що світ перевернувся, Слав-Ко-Ко намагається виправдати свій відхід від ідеалу письменника як сакральної фігури до інших орієнтирів. За його словами, «<..> немає зараз у моїй нещзасній державі ні повелителів, ні слуг - $\epsilon$ жертви перехідного періоду» [Верещак 2004:108]. Загальна неправильність, ненормальність, як ми бачимо, знов таки формує горизонтальну картину перверзійного світу, де не тільки нема духовної вертикалі, а й усі рівні у площині тотальних помилок, крутійства. «Жертовний» 
дискурс очуднюється, зокрема, невідповідністю високого статусу митця і точки зору його оцінки. Наприклад, кішка Фірся жаліє свого колишнього господаря й філософствує з приводу його недолугості: «Інтелігентна людина в період зміни культурної формаиї̈» [Верещак 2004:127].

Комерціалізація мистецтва отримує в п`єсі декілька інтерпретацій.

Перша - це прояв сучасної кризи культури, що втілюється у традиційному мотиві зради сакральних цінностей мотиві продажі души дияволу. Слав-Ко-Ко, підписавши вигідну угоду, що передбачала неправдиве зображення у творі небезпечної насправді ядерної станції, зраджує місії митця, обманює людей і наражає їх на небезпеку, тобто бере гріх на душу. Зауважимо, що цей епізод детально розписаний і в романі Я. Верещака «Вчасно обійняти верблюда, або Забави двійників-смертників», де він теж стає зав`язкою авантюрної за формою дії із серйозним філософським і моральним підтекстом. Безсумнівно, епізод стає алюзією на Чорнобильську катастрофу, що різко змінила сучасне світосприйняття i зумовила, за слушною думкою відомої дослідниці Тамари Гундорової, своєрідність українського постмодерну, специфіку художнього мислення на межі століть [Гундорова 2005]. Асоціації із цією подією та пошук мови інтерпретації нового художнього мислення, породженого культурним переломом, уводять твори Я. Верещака у широкий літературний контекст. Одночасно модельована в підтексті згадка про катастрофу підкріплює апокаліптичний дискурс твору i стає незаперечним критерієм оцінки поведінки героїв.

Власне, підписана героєм-драматургом угода i стає документом про продаж душі, що, судячи із бесіди двох митців, прекрасно розуміють творчі особистості, що пристосовуються до «перевернутого» часу і схильні так само змінити й уявлення про роль і сутність митця. Слав-Ко-Ко жартує: «Теперка знаю ціну душі своєї: 25 тисяч \$ США мінус податки. А тут мій колега режисер Девік, мудрий юдей, каже повагом: "Костю Костьовичу, побійся бога! Хіба можна стати таким видатним театральним діячем, як ти, $і$ зберегти душу?"» [Верещак 2004:100]. 
Безсумнівно, такий ракурс породжений основним конфліктом п’єси. Ми визначаємо його як зіткнення цінностей $\mathrm{i}$, відповідно, протиборство різних моделей митця (з одного боку - високої, сакралізованої, а з іншого - низької, продажної, комерціалізованої). На наш погляд, Я. Верещак випробовує різні творчі орієнтири. Переглядається не тільки роль митця як світського святого, а й символістська маска «дияволічного» поета (за А. Ханзеном-Леве). Показово, що друга теж суттєво знижується із статусу грішної але всесильної творчої особистості до «раба нікчемного», «бездарної пліткарки», «другорядного створіння», «дуринди», «лоха», «жебрака» [Верещак 2004:110;108;114]. У такий же спосіб перевертається символістська теорія життєтворчості: багато «сюжетів» життя, спроектованих Славком Ко-Ко, виявляються невдалими, а заклики до глядачів запропонувати «сюжети» виходу з ситуації лишаються без відгуку.

Таку ж провокаційну роль відіграє стратегія юродства, апофатичного доказу від протилежного. Вона сприяє очудненню й актуалізації широкого кола проблем: особистісного вибору, суті й природи творчості. Прикладом може бути блюзнірство героя, його театральна поведінка й акторствування перед глядачами, коли він після смерті, втративши тіло, знаходить на коліні душі шрам, що, наче, заперечує зникнення матеріальної оболонки Слав-Ко-Ко провокаційно філософствує, демонструє той шрам глядачам, карнавально закатує штанину і наче хвалиться цим рабським тавром як доказом існування у нього душі, яку вже встиг втратити у прижиттєвому крутійстві.

Саме завдяки своїм творчим здібностям та інтенціям протагоніст долає власний апокаліпсис і виходить із кризової ситуації перетвореним. Силою слова й любові до світу (які і $є$ його справжньою екзистенцією) Слав-Ко-Ко перетворює навіть смерть. Вона міняє образ: підступна холодна примара (Сусідка) теплішає, стає жінкою, захопленою поетичними замовляннями i чарами слів, а згодом і міняє сутність - із Чорного Ангела на Білого, тобто не відбирає, а повертає життя. Саме завдяки любові та слову герою вдається знайти мову спілкування із чарівним бджолиним роєм, який, за нашою думкою, 
втілює авторські уявлення про гармонічний космос, щастя, творчість. Притаманний перехідному мисленню апокаліптичний пафос замінюється оптимістичним, мотивами відродження, пасхальним архетипом. Акцентується майбутнє, новий етап розвитку і новий космос.

Ця інтенція виходить за межі конкретного образу, набирає ваги широкого узагальнення, про що свідчить фінал. У ньому у дещо комічному, карнавальному ключі подається й очуднюється ідея переходу, але вже не від життя до смерті (як це було на початку твору), а від одного кола життя до іншого, до наступного втілення, акцентується відсутність смерті й проголошується нове народження. Протагоніст, означений «Я», звертається до глядачів у залі з монологом, що максимально концентрує нову авторську картину світу, протистоїть попередній, «переверненій» моделі, повертає порушені норму й гармонію. Пропонується також концепція людини, яка екзистенційно прокинулась, усвідомила себе, зібралася. Філософський дискурс підтримують традиційні орієнтири: Бог, смерть, позитивні екзистенціали любові, гармонії, творчості. Метадискурс реалізується в мотиві слова, утвердженні його прагматичної сили й впливу всупереч постмодерній тотальній іронії. Метадискурс посилюється інтертекстуальністю, прийомом «тексту в тексті», а новий зміст, що виникає на кордонах текстів, містить ідею творчого відновлення світу через його образну інтерпретацію.

У п’єсі Ярослава Верещака таким кодовим поетичним ключем до гармонії, виходу у вищі світи стають рядки «Панни Інни», прямо названі молитвою й фактично означені як орієнтир національної культурної самоідентифікації. Внутрішньо протиставляючи позитивний екзистенціал любові новій агресивній цінності - багатству, Слав-ко-ко пригадує, як читав класичні рядки коханій: «I я читав для неї панну Інну як унікальну молитву україномовного більи-менш освіченого населення〉 [Верещак 2004:129]. Акцентується не розрив культурної традиції (як у Георгія Іванова), а наступність. Із цією метою широко цитуються вірші сучасника - поета Леоніда Кисельова, присвячені «Панні Інні». У новітньому творі класичні рядки також 
інтерпретовані як єдина достойна розмови з Богом висока мова, як позитивний екзистенціальний орієнтир.

У такий спосіб встановлюється діалог із традицією, моделюється орієнтир національної і культурної самоідентифікації, акцентується роль художнього слова у процесі культурного відродження після кризи.

Отже, Ярослав Верещак належить до плеяди драматургів «нової хвилі», а його високий статус поновлюється за модерністським орієнтиром Творця, i художні відкриття мають безсумнівний перспективний характер і наслідуються митцями, що прийшли в літературу в 2000-ні рр. Ці зв’язки драматургів різних творчих генерацій стануть предметом наших подальших наукових студій.

У драматургічних творах Ярослава Верещака послідовно формується метадискурс. Випробовуються можливості метадрами, рефлектуються іiі прийоми, проводяться плідні експерименти з розширення меж цієї форми. Доля митця, функції мистецтва, його можливості відображати складну історичну реальність і кризову сучасність стають ефективним ракурсом художнього дослідження світу, що потребує подальшого літературознавчого осмислення.

\section{БІБЛІОГРАФІЯ}

Бондарева 2006 - Бондарева О. С. Мiф i драма у новітньому літературному контексті : поновлення структурного зв'язку через жанрове моделювання: монографія / О. Є. Бондарєва. - К. : Четверта хвиля, 2006. $512 \mathrm{c}$.

Бондарева 2008 - Бондарева О. С. Новітня українська драматургія як відкрита нелінійна динамічна система / Олена Бондарева // Курбасівські читання: наук. вісник / Нац. центр театр. Мистец. ім. Леся Курбаса. - К., 2006 № 3. Ч. 2: Екзистенційний локус у новітній українській драматургії. - 2008. C. $124-162$.

Верещак 2004 - Верещак Я. Душа моя зі шрамом на коліні // Страйк ілюзій: Антологія сучасної української драматургії / Автор проекту та упорядник Н. Мірошниченко. - К. : Вид-во Соломії Павличко «Основи», 2004. - C. 97-137. 
Гундорова 2005 - Гундорова T. Післячорнобильська бібліотека. Український літературний постмодерн / Тамара Гундорова. - К. : Критика, 2005.

Мамчур 1988 - Мамчур I. Ознаки нового, або Спроба огляду сучасної української драматургії / І. Мамчур // Антракт. Театральний колаж. - К., 1988. C. $38-50$. 